Volume 13 Number 3, July-September 2019: pp. 289-306. Copyright (c) 2019 FIAT JUSTISIA. Faculty of Law, Lampung University, Bandarlampung, Lampung, Indonesia. ISSN: 1978-5186 | e-ISSN: 2477-6238. Open Access: http://jurnal.fh.unila.ac.id/index.php/fiat

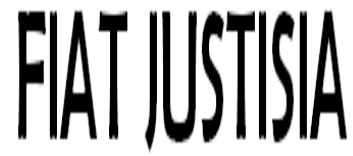

Fiat Justisia is licensed under a Creative Commons Attribution 4.0 International License, which permits unrestricted use, distribution, and reproduction in any medium, provided the original work is properly cited.

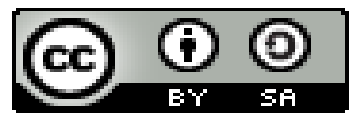

\title{
Organizational Culture as an Influencing and Mediating Factor between the Transformational Leadership and Work Satisfaction: an Empirical Study towards Police Integrity in the Police Headquarter of Central Java
}

\author{
Rycko Amelza Dahniel \\ Kepolisian Daerah Jawa Tengah, Indonesia \\ ryckoad@gmail.com
}

\begin{abstract}
The research investigates organizational structure as a mediating variable that influences the transformational leadership and the work satisfaction of police integrity in the areas under the jurisdiction of the Central Java's Police Headquarter. Police integrity is an important phenomenon, as it is the foundation for realizing trusted, modern, and professional police personnel, as expected by the Indonesian National Police (INP). The number of samples in this research was 200 police members from 10 working units in the Central Java's Police Headquarter. The sampling method was purposively random sampling. The Structural Equation Model Analysis (SEM) was used to test the influence of the transformational leadership and work satisfaction by placing organizational culture as a mediating variable against police integrity.

By the SEM analysis, this research found that police work satisfaction has influence over organizational culture ( $r=0.49 ; p<005)$, and the transformational leadership has significant influence over organizational culture $(r=0.37 ; p<0.05)$. Organizational culture as a mediating variable has significant influence over police integrity $(r=0.26 ; p<0.05)$. Furthermore, leadership has significant influence over police integrity ( $r=$ 0.39; $p<005)$, and work satisfaction has direct influence over police integrity $(r=0.24 ; p<0.05)$. Therefore, it can be concluded that the transformational leadership and work satisfaction have strong indirect influence over organizational culture as a mediating variable against police integrity.
\end{abstract}


Meanwhile, work satisfaction has weak direct influence $(r=0.24 ; p<0.05)$ over police integrity.

Keywords: Police Integrity, Transformational Leadership, Organizational Culture, Work Satisfaction.

How to Cite: Surya Dharma, "Organizational Culture as an Influencing and Mediating Factor between the Transformational Leadership and Work Satisfaction: an Empirical Study towards Police Integrity in the Police Headquarter of Central Java”, Fiat Justisia, 13 (3), (2019).

DOI: 10.25041/fiatjustisia.v13no3.1748

\section{A. Introduction}

The research investigates organizational structure as a mediating variable that influences the transformational leadership and the work satisfaction of police integrity in the areas under the jurisdiction of the Central Java's Police Headquarter. Police integrity is an important phenomenon, as it is the foundation for realizing trusted, modern, and professional police personnel, as expected by the Indonesian National Police (INP).

The phenomenon of police integrity has become an important topic discussed in a professional police environment and many academic kinds of literature ${ }^{1}$ in various countries, ${ }^{2}$ considering multiple violations committed by the police. Police integrity has also become an important issue in Indonesia. As a result, INP's bureaucratic reform has been focused on improvements in instrumental, structural, and cultural fields. Cultural change has become very strategic and essential, as this dimension is related to integrity value reforms and to a mindset that puts forward the importance of professional, modern, and trusted police services in realizing security and public order.

Police integrity issue is still concerning, as reported by the Global Corruption Barometer (2017), which stated that INP was considered the most corrupt institution in Indonesia (cnnindonesia.com). Furthermore, a survey on 36 ministries/agencies and 30 local governments conducted by the Corruption Eradication Commission (KPK) in 2017 showed that INP had the second lower rank in integrity (cnnindonesia.com). These findings had become important considerations to conduct this research, focusing on

\footnotetext{
${ }^{1}$ Klockars, C.B, "Some really cheap ways of measuring what really matters", in Langworthy, R.H (Ed.) Measuring What Matters: Proceedings from the Policing Research Institute Meetings, Washington DC: Departmentof Justice, National Institute of Justice, (1999), pp. 195214.

${ }^{2}$ Goldstein, H, Police Corruption: A Perspective on its Nature and Control, Police Foundation, Washington DC, (1975), pp. 20-25.
} 
transformational leadership, organizational culture, and work satisfaction variables. The three variables influence police integrity in implementing his or her duties. Therefore, this research tries to answer a research question about the influence of the organizational culture mediation, the transformational leadership, and the work satisfaction of police integrity in the Central Java's Police Headquarter.

The effort to develop and internalize police members' integrity values is the core dimension for the realization of democratic police. Integrity values that are implemented by police members will have positive implications for police behavior, which puts forward rules, ethics, and non-discriminatory treatments. Integrity values upheld by police members become vital indicators for the success in realizing democratic police. ${ }^{3}$

The problem to be discussed in this research is related about how the application of legal principles in organizational cultural relations as a mediating influence factor between Transformational Leadership and Work Satisfaction: an Empirical Study on the Police Integrity in the Central Java's Police Headquarterand what are the influencing factorsbetween Transformational Leadership and Work Satisfaction: an Empirical Study on the Police Integrity in the Central Java's Police Headquarter.

The Organizational Theory states that police integrity is the inclination for police members to refuse any abuse of powers or violation of authorities, as the norms and ethics of police work. Police integrity has various interpretations, perceived from the police misconduct aspect. As a result, police members will have different police integrity phenomena in refusing numerous temptations in his or her duties. ${ }^{4}$

Police organizations in many countries have given serious attention to violations by police members. Several rules and sanctions have been developed as an effort to prevent unethical behavior. ${ }^{5}$ External monitoring over integrity seems not optimal, so it needs to be focused even more. Klockars conducted a study on police integrity that was quite comprehensive .et.al. ${ }^{6}$ This study examines police integrity from an aesthetic point of view.

\footnotetext{
${ }^{3}$ Sanja KutnjakIvkovic, Wook Kang, "Police Integrity in South Korea", Policing: An International Journal of Police Strategies \& Management, 35 (1), (2012), pp. 285-286.

${ }^{4}$ C.B. Klockars, S. KutnjakIvković, W.E Harver, and M.R. Haberfeld, The Measurement of Police Integrity.Final Report to the National Institute of Justice (NIJ Grant 95-IJ-CX-0058), Washington DC: The Cross Cultural Study of Police Corruption), Office of Justice Programs. National Institute of Justice. US Department of Justice, (1997), pp 27-30.

${ }^{5}$ M. Pagon, Policing in Central and Eastern Europe: Ethics, Integrity, and Human Rights, Ljubljana: College of Police and Security Studies, (2000), pp 197-209.

${ }^{6}$ C. B. Klockars, S. K. Ivković, \& M. R. Haberfeld, The Contours of Police Integrity. In: C. B. Klockars, S. K. Ivković \& M. R. Haberfeld, eds. The Contours of Police Integrity. London: SAGE Publications, (2004), pp. 1-18.
} 
According to Klockarset.al. ${ }^{7}$ police integrity consists of normative dimensions: the inclination to refuse; police as individuals and groups; temptations; the abuse of position; and the rights and work advantages.

Klockars et al. ${ }^{8}$ define police integrity as the normative inclination amongst police members to defend themselves from the temptations of abusing rights and abusing the privileges of their jobs. Honesty is an essential element for police members, as integrity is a substance that glues together police and the existing legal system. ${ }^{9}$ Actions and behavior of police officers who have high integrity will help improve the relationship between police and society, making the police more accountable and transparent. It will grow people's confidence in INP..$^{10}$ All kinds of violations and deviations conducted by police officers will not only cost individuals and the society that they serve but will also taint the image of the police organizations as a whole. It has prompted this research on police integrity.

The transformational leadership is a process towards the change in behavior and towards developing the commitments of organizational members in achieving the goals of the organization. ${ }^{11}$ As a result, the transformational leadership promotes the use of intellectual capabilities of its followers. ${ }^{12}$ Transformational leadership is a type of leadership that encourages changes for individuals and a social system in an organization. In the concept of transformational leadership, ${ }^{13}$ there are four leadership behavior dimensions: (1) idealized influence, (2) inspirational motivations, (3) intellectual stimulation, and (4) individualized considerations. Transformational leadership is expected to improve motivation, morale, and the performance of organization members. ${ }^{14}$

\footnotetext{
${ }^{7}$ C. B. Klockars, S. K. Ivković, \& M. R. Haberfeld, Enhancing Police Integrity. Research for Practice. Office of Justice Programs, National Institute of Justice, Washington DC: US Department of Justice, (2005). pp 13-16.

${ }^{8}$ Klockars, Carl B, Sanja Kutnjak Ivković \& M.R. Haberfeld, Enhancing Police Integrity, Netherlands: Springer, (2006),pp 70-76.

${ }^{9}$ P. Van Reenen, "Police Integrity and Police Loyalty: Stalker Dilemmma" Policing and Society, 8 (1), (1997), pp 43-45.

${ }^{10} \mathrm{Ibid}$.

${ }^{11}$ G. Yuki, \& D. D Van Fleet, Theory and Research on Leadership in Organizations. In M.D. Dunnette, \& L.M. Hough (Eds.), Handbook of Industrial and Organizational Psychology, Vol. 3, pp 147-197. Palo Altyo, CA: Consulting Psychologists Press, (1992).

12 J. N. Cleveland, M. Stockdale, \& K. R. Murphy, Applied psychology series. Women and men in organizations: Sex and gender issues at work. Mahwah, NJ, US: Lawrence Erlbaum Associates Publishers, (2000), pp 10-15.

${ }^{13}$ B. M Bass, Transformational Leadership: Industrial, Military, and Educational Impact. Mahwah, NJ: Erlbaum, (1998), pp 65-76.

${ }^{14}$ Pan Xiaoxia, Transformational Leadership VS Transactional Leadership: The Influence of Gender and Culture on Leadership Style of SMES in China and Sweden, (2006), pp 2-8.
} 
The organizational culture developed by Hofstede ${ }^{15}$ has four dimensions: (1) power distance, (2) collectivism vs. individualism, (3) feminist vs. masculinist; and (4) uncertainty avoidance. This organizational culture is a mediating variable that is used to test the influence of the transformational leadership and the police members' work satisfaction of police integrity. Developing influential culture in an organization can improve the organization's competitiveness, ${ }^{16}$ so the members of the organization understand what needs to be done, and also how it should be done for the organization.

The work satisfaction of organizational members can influence the actions and behavior against the organization, so their positive behavior against the organization has become an essential element in the organization. Work satisfaction is excellent, positive emotional feelings received from proper job assessment and the experience of an organizational member ${ }^{17}$. The work satisfaction of organizational members has two dimensions: hygiene and motivating factors, ${ }^{18}$ which provide the relevant theoretical framework related to the work satisfaction of members of organizations. According to Herzberg etal., ${ }^{19}$ organization members will not only be satisfied with their ability to fulfill their basic needs -- such as the safety in work environment, salaries, working conditions -- but they will also be confident with related work responsibilities, career development, self-actualization, recognition, and right working conditions.

Using the above-mentioned literature review, a hypothetic model is tested using the Partial Least Square(PLS) (smart PLS 2.0 program). The organizational culture variable is tested against four dimensions. The work satisfaction variable was tested against two aspects. The transformational leadership variable was tested against five sizes. The police integrity variable was tested against 11 variables. The SEM model that is tested in this research will be explained in the following model. Police integrity is the dependent variable, while organizational culture is the mediating variable that connects the transformational leadership model with the work satisfaction of police integrity. This hypothetic model also shows the direct influence of the transformational leadership and the work satisfaction over police integrity, so the path analysis will also show a hypothetical indirectrelationship between

\footnotetext{
${ }^{15}$ G Hofstede, Cultures and Organizations: Software of the Mind, UK: Mc Graw-Hill Books, (2005), pp 80-87.

${ }^{16}$ W. R Scott, Organizations: Rational, Natural, and Open Systems. Upper Saddle River, NJ: Prentice Hall, (1998), pp 42-48.

${ }^{17}$ Edwin A Lock, "Job Satisfaction and Job Performance: A Theoritical Analysis", Organization Behavior and Human Performance, 30 (6), (1976), pp. 890-899.

${ }^{18}$ F. Herzberg, B. Mausner, \& B. B. Snyderman. TheMotivation to Work. New York: John Wiley \& Sons, (2003), pp 87-93.

${ }^{19}$ Ibid.
} 
the transformational leadership and work satisfaction variables and the organizational culture and police integrity. This theoretical model will also show the direct influence of transformational leadership and work satisfaction over police integrity.

\section{Picture 1 Hypothetic Model}

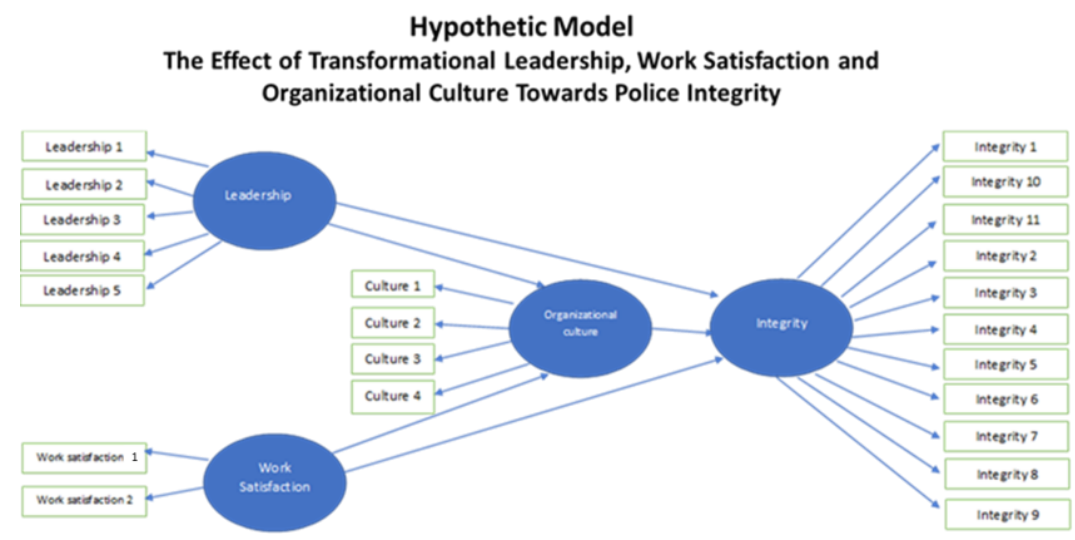

\section{B. Research Method}

The research involved 200 police officers from six functional police units in the Central Java's Police Headquarter, including the Directorate of Frontline Policing, the Directorate of Economic and Special Crimes, the Directorate of General Crime, the Directorate of Narcotic Crime, the Directorate of Community Policing, and the Directorate of Traffic Police. The sampling method was the purposively random sampling, meaning that the samples (the police officers) were taken from working units that had many interactions with the society. Questioners, which measured police integrity, organizational culture, transformational leadership, and work satisfaction, were distributed amongst police members in six functional police units. A summary of the research variables can be found in Table 1 below.

The integrity variable uses 11 scenarios of measuring police integrity developed by Klockars.et.al. ${ }^{20}$ The organizational culture consists of four dimensions: (1) power distance, (2) individualism vs. collectivism, (3) uncertainty avoidance, and (4) masculinity vs. femininity, developed by Hofstede. ${ }^{21}$ The transformational variable comprises four dimensions: (1)

${ }^{20}$ C. B. Klockars, S. K. Ivković, \& M. R. Haberfeld, The Contours of Police Integrity. In: C. B. Klockars, S. K. Ivković \& M. R. Haberfeld, eds. The Contours of Police Integrity. London: SAGE Publications, (2004), pp. 1-18.

${ }^{21}$ G. Hofstede, Cultures and Organizations: Software of the Mind, UK: McGraw-Hill Books, (2005), pp.62-67. 
idealized influence, (2) inspirational motivation, (3) intellectual stimulation, and (4) individualized consideration, introduced by Bass \&Avolio. ${ }^{22}$ The work satisfaction variable consists of intrinsic and extrinsic dimensions developed by Herzberg.et.al., ${ }^{23}$

Table 1. Research Variables and Dimensions

\begin{tabular}{|c|c|c|c|}
\hline No & Variables & Dimensions & Sources \\
\hline 1 & Police integrity & 11 scenarios & Klockers, et al., ${ }^{24}$ \\
\hline \multirow[t]{4}{*}{2} & \multirow{4}{*}{$\begin{array}{l}\text { The } \\
\text { transformational } \\
\text { leadership }\end{array}$} & 1. Idealized Influence & \multirow{4}{*}{$\begin{array}{l}\text { MLQ (Bass } \\
\& \text { Avolio }^{25} \text { ) }\end{array}$} \\
\hline & & $\begin{array}{l}\text { 2. Inspirational } \\
\text { motivation }\end{array}$ & \\
\hline & & $\begin{array}{l}\text { 3. Intellectual } \\
\text { stimulation }\end{array}$ & \\
\hline & & $\begin{array}{l}\text { 4. Individualized } \\
\text { consideration }\end{array}$ & \\
\hline \multirow{4}{*}{3} & \multirow{4}{*}{$\begin{array}{l}\text { Organizational } \\
\text { culture }\end{array}$} & 1. Power distance & \multirow[t]{4}{*}{ Hoftsede $^{26}$} \\
\hline & & $\begin{array}{l}\text { 2. Individualism vs. } \\
\text { collectivism }\end{array}$ & \\
\hline & & $\begin{array}{l}\text { 3. Uncertainty } \\
\text { avoidance }\end{array}$ & \\
\hline & & $\begin{array}{l}\text { 4. Masculine vs. } \\
\text { femininity }\end{array}$ & \\
\hline 4 & & 1.Extrinsic & Herzberg $^{27}$ \\
\hline
\end{tabular}

22 B.M. Bass, \& B.J. Avolio, (Eds.) Improving Organizational Effectiveness through Transformational Leadership, Thousand Oaks, CA: Sage Publications, (1994), pp 47-56.

${ }^{23}$ F. Herzberg, B. Mausner, \& B. B. Snyderman, TheMotivation to Work, New York: John Wiley \& Sons, (2003), pp. 70-74.

${ }^{24}$ C. B. Klockars, S. K. Ivković, \& M. R. Haberfeld, The Contours of Police Integrity. In: C. B. Klockars, S. K. Ivković \& M. R. Haberfeld, eds. The Contours of Police Integrity, London: SAGE Publications, (2004), pp. 22-26.

25 B.M. Bass, \& B.J. Avolio (Eds.), Improving organizational effectiveness through transformational leadership. Thousand Oaks, CA: Sage Publications, (1994), pp 52-58.

${ }^{26}$ G. Hofstede, Cultures and Organizations: Software of the Mind, UK: Mc Graw-Hill Books, (2005), pp. 40-47.

${ }^{27}$ F. Herzberg, B. Mausner, \& Snyderman, B. B, The Motivation to Work, New York: John Wiley \& Sons, (2003), pp. 33-38. 


\begin{tabular}{|l|l|l|l|}
$\begin{array}{l}\text { Works } \\
\text { satisfaction }\end{array}$ & 2.Intrinsic & \\
\hline
\end{tabular}

Data analysis uses the path analysis and the Structural Equation Model (SEM) to test organizational culture as a mediating variable that influences the transformational leadership and the work satisfaction of police integrity in the Central Java's Police Headquarter.

\section{Discussions}

\section{The Application of Legal Principles in Organizational Culture Relations as a Mediating and Influencing Factors Between Transformational Leadership and Work Satisfaction}

The duties and functions of the police force are universal to maintain the security and order of the people by applicable legal provisions and to elevate awareness of legal certainty and justice in Indonesia. These functions and tasks have been regulated in several statutory requirements, one of which is Law Number 2 of 2002 concerning the Indonesian National Police. This law has expanded the functions and duties of the Police which include the maintenance of security and public order, law enforcement, and protection and services to the community by upholding human rights. ${ }^{28}$

The police, as a legal apparatus in a law state, do not mean to be immune before the law. The police in Indonesia remain bound by the rule of law, legal procedures, and at the same time accountable under the law. ${ }^{29}$ The legal liability system for the Police in Indonesia is not much different from the legal liability for civil society in general, such as through administrative law and criminal law for acts of irregularity or arbitrariness of the Police in an organizational or personal way in carrying out their functions. Deviations of police behavior are a general description of police officers' activities that are not by official authority, organizational authority, values, and standards of polite behavior (which are usually carried out, not just said). ${ }^{30}$

The police in carrying out their duties as law enforcers, not only must obey the applicable law as an external aspect, they are also equipped with police ethics as an aspect of the police force. Police ethics are norms about police

28 Dwi Indah Widodo, "Penegakan Hukum Terhadap Anggota Kepolisian yang Menyalahgunakan Narkotika dan Psikotropika", Jurnal Hukum Magnum Opus, I (1), (2018), hlm. 2.

29 Untung S. Rajab, Kedudukan dan Fungsi Polisi Republik Indonesia alam SistemKetatanegaraan, Bandung: Utomo, (2003), p. 145.

${ }^{30}$ Barker, Thomas and David L. Carter, Police Deviance, Third Edition, translated by Kunarto da nKhobibah M. Arief Dimyanti, Jakarta: Cipta Manunggal, (1999), p. 4. 
behavior to be used as guidelines in realizing the implementation of good duties for law enforcement, public order and public safety. ${ }^{31}$ The police who are unethical and have no integrity in their duties will become parasites of justice creating the Criminal Justice System (SPP) as a vicious circle of the judicial mafia. ${ }^{32}$ So, in this case, the integrity of the police is also related to the law in Indonesia.

As already mentioned that the Police in Indonesia (POLRI) carry out their duties based on Law Number 2 of 2002, including the integrity of POLRI based on the principles contained in that law. Based on Article 4 and Article 5 of Law Number 2 of 2002, the Indonesian National Police has objectives and roles based on the principle of awareness domestic security which includes maintaining public order and safety, orderly and upholding the law, implementation of protection, and services to the community, as well as maintaining peace of society by supporting human rights. The main functions and tasks of the Indonesian National Police are regulated in Article 2 and Article 13, which are based on the principle of maintaining public order and security; law enforcement; and protection, protection and service to the community - then related to the integrity of the Indonesian National Police in carrying out its duties and authorities based on the principles contained in Article 19 namely on legal norms, religious norms, politeness, decency, and upholding human rights.

It is related to the basic principles that form the basis of the policy contained in the Regulation of the Chief of the Indonesian National Police Number 8 of 2009 concerning the Implementation of the Principles and Standards of Human Rights in the Implementation of the Duties of the Indonesian National Police. This regulation contains various underlying principles and principles of the National Police in carrying out its duties and functions. The principles which form the basis for the establishment of Regulation No. 8/2009 are contained in the weighing part of the regulation, namely maintaining public order and security, law enforcement, protection, protection, and service to the community; respect, protect and uphold human rights in carrying out their duties and functions; respect, protect and enforce human rights in carrying out their responsibilities and services, it is necessary to provide guidance on the implementation of human rights principles and standards in the execution of the functions and duties of the Indonesian National Police. In this case it can be seen that in carrying out its duties, the National Police is based on human rights principles.

Furthermore, regarding human rights which are the protection of Kepolisian Negara Republik Indonesia, it is explained in Article 3 to Article

\footnotetext{
${ }^{31}$ Kunarto, Etika Kepolisian, Jakarta: CiptaManunggal, (1997),hlm. 97

${ }^{32}$ Agus Raharjo dan Angkasa, "Profesionalisme Polisi Dalam Penegakan Hukum", Jurnal Dinamika Hukum, 11 (3), (2011), p. 390
} 
8 of Regulation No. 8 of 2009. Then in Article 9 it is stated that in implementing the service and protection duties of the community, every member of the National Police must pay attention to the principles of legality, the law of necessity, the principle of proportionality. So, in this case, it can be said that the Indonesian National Police is not only bound to the basic principles of law, but also the principles of law. Then Article 35 Chapter IV states that POLRI also respects one of the essential principles in law, namely the principle of presumption of innocence. So basically, the integrity of the Indonesian National Police is based on basic human rights principles.

\section{Influencing Factors Between Transformational Leadership and Work Satisfaction: An Empirical Study on the Police Integrity in the Central Java's Police Headquarter}

The results of the descriptive analysis of police integrity provide a description of police members' responses to 11 scenarios of measuring police integrity developed by Klockars et.al.(2004) (using answer options (1) very unserious (STS) (2) not severe (TS), (3) no problem (B), (4) serious (S) and (5) very serious (SS) for the 11 scenarios (Graph 4.18 Page 121 regarding the 11 scenes in Klokars et.al.(2004)). The most severe integrity violation according to the respondents was Scenario 5 (a police officer examined a crime scene of a jewelry shop robbery, took a watch, and reported that the watch was stolen during the burglary). The second most serious integrity violation according to the respondents was Scenario 3 (a police officer stopped a driver who violated a traffic rule and received bribery not to write a traffic violation ticket). 
Graph 1 the Police Integrity Variable

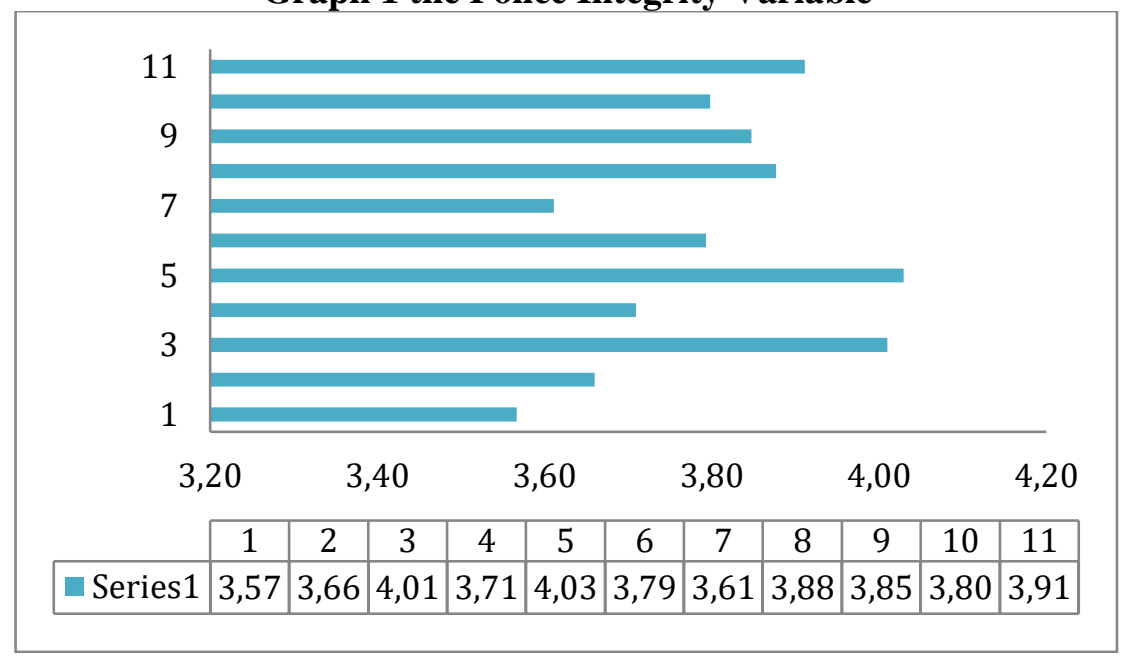

In the above Graph, one of the most severe violations of police integrity is Scenario 11 (a police officer found a wallet in a parking lot, reported the case, but took away Rp 500 thousand from the wallet). Scenario 11 is the third most serious violation according to the respondents. The least serious integrity violation is Scenario 1 (a police officer ran a business, selling security equipment, such as alarm systems, CCTV cameras, etc). Respondents perceived this as a not severe integrity violation. Another scenario deemed not dangerous is Scenario 7 (a police officer is a good car technician, so his supervisor allowed him or her to take a day-off to fix the supervisor's car). The research found that the phenomenon of allowing a member of organization to take a day-off for the personal interest of the leader is not a severe issue to police integrity. This phenomenon shows a leader who uses his hierarchical authority for his or her interests and benefits, as the tasking given to the subordinate is not related to his or her official work.

From five transformational leadership dimensions, the inspirational motivation dimension is the highest one, according to the respondents. The respondents hoped that the leader could give inspirations and motivation to the subordinates so that they could uphold police ethics, accountability, and professionalism. Integrity is values that police officers have to support because in their duties police officers have many interactions with the people in the society. It has the potential for ethical violations.

\section{Graph 2. The Transformational Leadership Variable}




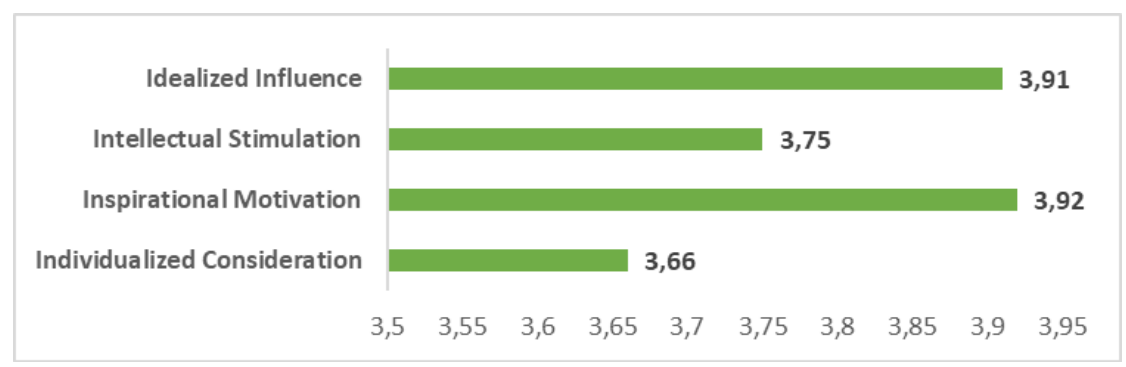

The Graph also shows that respondents needed a leader that could provide good working conditions so that they could work with the leader. The good working conditions and the environment will make the subordinates happy and proud to work with the leader. The inspirational dimension has the strongest relationship with the transformational leadership $(r=0.870 ; p<0.05)$.

According to the respondents, the descriptive analysis of the work satisfaction variable shows that the intrinsic dimension is more important than the hygiene dimension. It is shown in the Graph below.

\section{Graph 3. The Work Satisfaction Variable}

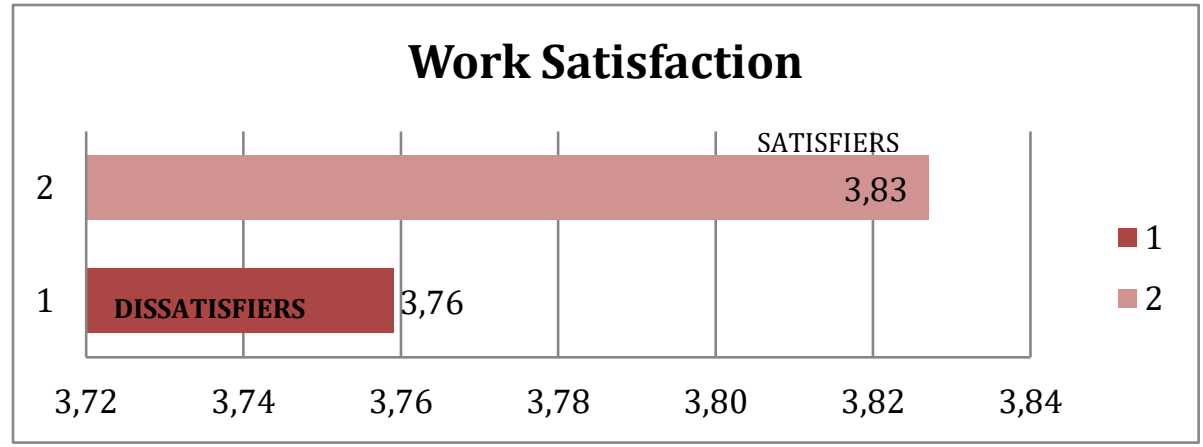

The work satisfaction dimension, which is intrinsic (satisfier), shows that the respondents needed factors on personal development and work acknowledgement. Meanwhile, the externalaspect (dis-satisfier) shows that the respondents needed tangible elements, which were below the satisfiers.

Regarding the descriptive analysis of the organizational culture, the uncertainty avoidance dimension was deemed more important than the power distance dimension, according to the respondents.

\section{Graph 4. The Organizational Culture Variable}




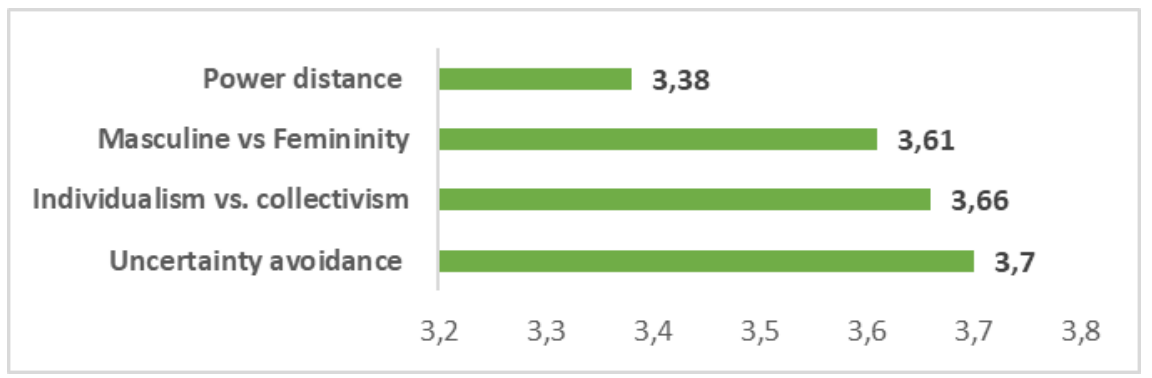

The Graph above shows that police member would to like have a hierarchical relationship that was not stiff (power distance, which is characterized by a bureaucratic structure) so that the communication between subordinates and the leader became more effective in fulfilling their duties. The high response from the respondents to the uncertainty avoidance dimension shows that police members wanted to be always proactive to respond to changes in the organizational environment.

This SEM Model analysis was conducted to show a causal relationship between organizational culture as a mediating variable and the transformational leadership and work satisfaction of police integrity. The hypothetical relationship can be seen in the Graph below.

\section{A Hypothetical Relationship Model between Organizational Culture as a Mediating Variable and the Transformational Leadership and Work Satisfaction of PoliceIntegrity}

Picture 2 Finding SEM Model

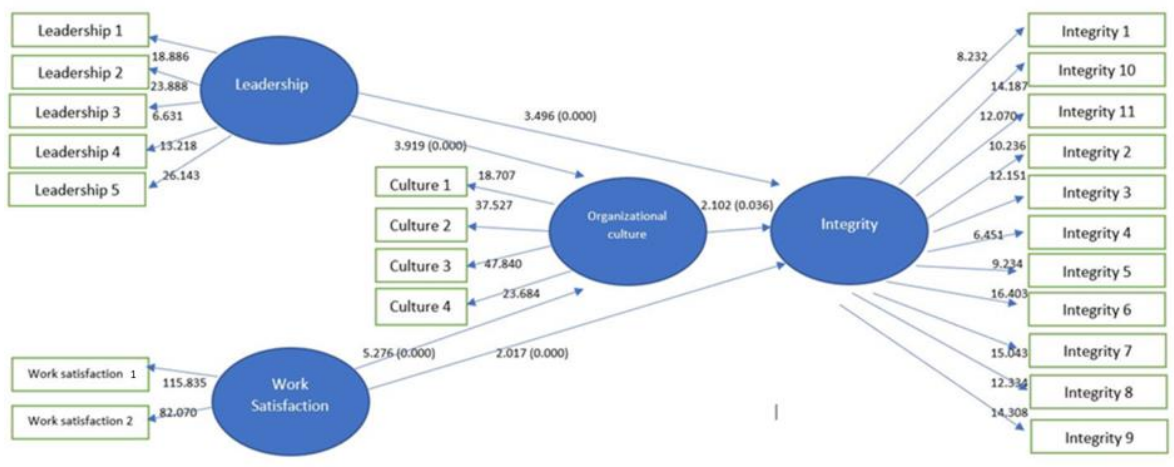

The Graph below provides the answer to the above hypothetical model. The analysis shows that the transformational leadership variable has significant influence over organizational culture $(r=0.37 ; p<0.05)$, and work satisfaction has significant influence over organizational culture $(r=0.49 ; p<$ 
0.05). Furthermore, organizational culture as a mediating variable has significant influence over police integrity $(\mathrm{r}=0.26 ; \mathrm{p}<0.05)$. In the Graph above, the leadership variable has significant direct influence over police integrity $(\mathrm{r}=0.38 ; \mathrm{p}<0.05)$, and work satisfaction has significant direct influence over police integrity $(\mathrm{r}=0.24 ; \mathrm{p}<0.05)$. In general, the work satisfaction variable has the stronger influence (compared to organizational structure) over organizational culture.

The transformational leadership variable has significant direct influence over police integrity $(\mathrm{r}=0.38 ; \mathrm{p}<0.05)$, while it has indirect influence over organizational culture $(r=0.37 ; p<0.05)$. The results of the SEM test shows that all variables have significant influence over police integrity, so the transformational leadership, work satisfaction, and organizational structure variables become important factors in the effort to improve police integrity $(\mathrm{r}=0.24, \mathrm{p}<0.05)$. These three variables have significant indirect influence over organizational culture $(r=0.48 ; \mathrm{p}<0.05)$. Police members' works satisfaction has the potential to form organizational culture. The organizational culture will, in turn, have implications for police integrity. Therefore, cultural reform in a police organization becomes a very crucial, strategic factor in realizing police integrity.

This research confirms Schein Theory (2002), which maintains that leadership and organizational culture are two sides of a coin, meaning leadership and organizational culture are inseparable factors. A corporate culture that has internalized integrity values, public services, accountability, and transparency is a culture that needs to be developed in a police organization. A police organization that has managed to internalize those values always needs and hopes for a leader that can maintain an influential organizational culture.

Picture 3 Finding SEM Model

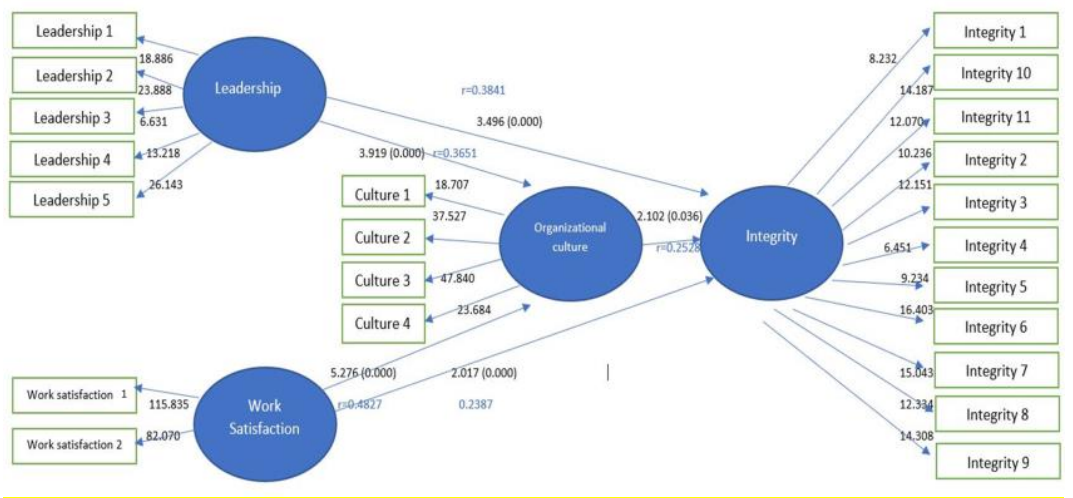

\section{Conclusions}


The conclusion from the research is that the counter of integrity was perceived differently by the respondents based on the values, culture and the way of their life. The study shows that bribery was considered a severe violation by police officers. Meanwhile, the research shows that a police officer selling security equipment was not perceived as a serious integrity violation. As a result, this scenario is not regarded as a conflict of interest. The respondents believe that as long as this business did not relate to the police organization, it would not consider as an unethical behavior because the products they sold to fulfill the need of the community.

Most police officers perceived the scenarios of measuring police integrity using the robbery and bribery phenomena as serious violations. This conclusion is similar to the findings of research activities in several other countries (Klockars.et.al.2004). In general, the leadership factor is an important, strategic factor to develop police integrity through the development of an organizational structure that upholds professionalism, accountability, and accountability in fulfilling duties in the field. Police members' work satisfaction is also essential in the effort to strengthen integrity values amongst police members. They should be given attention to their career development. They should also be empowered in the police organization.

\section{A. Book}

\section{Bibliography}

Barker, Thomas and David L. Carter. (1999).Police Deviance, Third Edition, translated by KunartodanKhobibah M. AriefDimyanti, Jakarta: CiptaManunggal.

Bass, B. M. (1998). Transformational Leadership: Industrial, Military, and Educational Impact. Mahwah, NJ: Erlbaum.

Bass, B.M. \& Avolio, B.J. (Eds.). (1994). Improving OrganizationalEffectiveness Through Transformational Leadership. Thousand Oaks, CA: Sage Publications.

Cleveland, J. N., Stockdale, M., \& Murphy, K. R. (2000). Applied psychology series. Women and Men in Organizations: Sex and Gender Issues At Work. Mahwah, NJ, US: Lawrence Erlbaum Associates j

Goldstein, H. (1975).Police Corruption: A Perspective on its Nature and Control, Police Foundation, Washington DC.

Herzberg, F., Mausner, B., \& Snyderman, B. B. (2003). The Motivation to Work. New York: John Wiley \& Sons.

Hofstede, G. (2005). Cultures and Organizations: Software of the Mind. UK: McGraw-Hill Books.

Klockars, C. B., Ivković, S. K. \&Haberfeld, M. R., (2004).The Contours of Police Integrity. In: C. B. Klockars, S. K. Ivković\& M. R. Haberfeld, eds. The Contours of Police Integrity. London: SAGE Publications. 
Klockars, C.B (1999), "Some Really Cheap Ways of Measuring What Really Matters", in Langworthy, R.H (Ed.) Measuring What Matters: Proceedings from the Policing Research Institute Meetings. Washington, DC: Departmentof Justice, National Institute of Justice.

Klockars, Carl B, SanjaKutnjakIvković\& M.R. Haberfeld. (2006). Enhancing Police Integrity. Netherlands: Springer.

Klockars,C.B., KutnjakIvković, S. and Haberfeld, M.R. (2005). Enhancing Police Integrity. Research for Practice.Office of Justice Programs. Washington DC: National Institute of Justice, US Department of Justice. Klockars,C.B., KutnjakIvković, S., Harver, W.E. and Haberfeld, M.R. (1997). The Measurement of Police Integrity.Final Report to the National Institute of Justice (NIJ Grant 95-IJ-CX-0058. Washington DC: The Cross Cultural Study of Police Corruption), Office of Justice Programs. National Institute of Justice. US Department of Justice.

Kunarto. (1997). EtikaKepolisian. Jakarta: Cipta Manunggal.

Pagon,M. (2000). Policing in Central and Eastern Europe: Ethics, Integrity, and Human Rights.Ljubljana: College of Police and Security Studies.

Scott, W.R. (1998). Organizations: Rational, Natural, and Open Systems. Upper Saddle River, NJ: Prentice Hall.

Rajab, Untung S. (2003). Kedudukan dan Fungsi Polisi Republik Indonesia dalam Sistem Ketatanegaraan. Bandung: Utomo.

Yuki, G., \& Van Fleet, D. D. (1992). Theory and Research on Leadership in Organizations. In M.D. Dunnette, \& L.M. Hough (Eds.), Handbook of Industrial and Organizational Psychology, Vol. 3 (pp 147-197). Palo Altyo, CA: Consulting Psychologists Press.

\section{B. Journal and Article}

Agus Raharjo dan Angkasa, "Profesionalisme Polisi Dalam Penegakan Hukum", Jurnal Dinamika Hukum, 11 (3), (2011), https://doi.org/10.20884/1.jdh.2011.11.3.167 .

Dwi Indah Widodo, "Penegakan Hukum Terhadap Anggota Kepolisian Yang Menyalahgunakan Narkotika dan Psikotropika", Jurnal Hukum Magnum Opus, I (1), (2018), https://doi.org/10.30996/jhmo.v0i0.1762 .

Edwin A Lock, "Job Satisfaction and Job Performance: A Theoritical Analysis", Organization Behavior and Human Performance, 30(6), (1976), https://doi.org/10.1016/0030-5073(70)90036-x .

P. van Reenen, "Police Integrity and Police Loyalty: Stalker Dilemma" Policing and Society, 8 (1), https://doi.org/10.1080/10439463.1997.9964780 . 
Pan Xiaoxia, Transformational Leadership VS Transactional Leadership: The Influence of Gender and Culture on Leadership Style of SMES in China and Sweden, (2006).

Sanja Kutnjak Ivkovic, Wook Kang, "Police Integrity in South Korea", Policing: An International Journal of Police Strategies \& Management, 35 (1), (2012),https://doi.org/10.1007/978-1-49392279-6_9 . 
